University of Nebraska - Lincoln

DigitalCommons@University of Nebraska - Lincoln

1976

\title{
PROSPECTS FOR CONTROL OF PHYTOPATHOGENIC BACTERIA BY BACTERIOPHAGES AND BACTERIOCINS
}

Anne K. Vidaver

University of Nebraska - Lincoln

Follow this and additional works at: https://digitalcommons.unl.edu/plantpathpapers

Part of the Other Plant Sciences Commons, Plant Biology Commons, and the Plant Pathology

Commons

Vidaver, Anne K., "PROSPECTS FOR CONTROL OF PHYTOPATHOGENIC BACTERIA BY BACTERIOPHAGES AND BACTERIOCINS" (1976). Papers in Plant Pathology. 636.

https://digitalcommons.unl.edu/plantpathpapers/636

This Article is brought to you for free and open access by the Plant Pathology Department at DigitalCommons@University of Nebraska - Lincoln. It has been accepted for inclusion in Papers in Plant Pathology by an authorized administrator of DigitalCommons@University of Nebraska - Lincoln. 


\title{
PROSPECTS FOR CONTROL OF PHYTOPATHOGENIC BACTERIA BY BACTERIOPHAGES AND BACTERIOCINS
}

\author{
Anne K. Vidaver ${ }^{1}$ \\ Department of Plant Pathology, University of Nebraska, Lincoln, Nebraska 68583

\section{INTRODUCTION}

The last review on bacteriophages and bacteriocins of phytopathogenic bacteria was that of Okabe \& Goto (98). All but one (21) of the subsequent reviews (11, $12,60,94,104)$ have dealt primarily with viruses and bacteriocins of bacteria other than phytopathogens. The most recent microbiological compendia that include bacteriophages and bacteriocins are of limited value for phytobacteriologists because the authors generally overlook or ignore such agents $(29,47,77$, 119). However, Adam's classic book (4), the review by Bradley (11), and the bibliography of Raettig (102) are still of value to phytobacteriologists as are reviews dealing principally with methods $(7,39,65,66,83,99)$.

In this review, the current and future prospects for control of bacterial plant pathogens with phages and bacteriocins are evaluated. Some general comments on the phages and bacteriocins of phytopathogenic bacteria are presented, but biological, chemical, and physical characteristics are not discussed in detail. Readers interested in these areas may refer to the supplementary bibliography. ${ }^{2}$

\section{TERMINOLOGY AND TAXONOMY}

Nomenclature of phytopathogenic bacteria is unsettled, particularly for Pseudomonas and Xanthomonas species. In this review, I employ nomenclature useful to

\footnotetext{
${ }^{1}$ Published with the approval of the Director as paper no. 5049, Journal Series, Nebraska Agricultural Experiment Station. The work was conducted under Nebraska Agricultural Experiment Station Project No. 21-21.

${ }^{2}$ For supplementary bibliographic material (113 refs., 14 pgs.) order NAPS document 02863 from ASIS, c/o Microfiche Publications, 440 Park Ave. S., NY, NY 10017. Remit in advance for each NAPS accession number $\$ 1.50$ for microfiche or $\$ 5.00$ for each photocopy. Make checks payable to Microfiche Publications.
} 
plant pathologists. Thus, the nomenspecies of Dye et al (33) are used for all Pseudomonas species designated as $P$. syringae by Doudoroff \& Palleroni in the eighth edition of Bergey's manual (30). Likewise, I cite the nomenspecies listed in Addendum I of Dye \& Lelliot (34) for all the Xanthomonas grouped into $X$. campestris. Retention of many of these Xanthomonas nomenspecies is supported by DNA homology data (89). Other genera and species are presented as in the eighth edition of Bergey's manual.

Most investigators agree on what constitutes a bacteriophage, although it is not yet clear where noninfectious particles resembling phages or phage components fit into current phage classification schemes (3). In any case, since relatively few bacteriophages of phytopathogenic bacteria have been characterized sufficiently for inclusion into current distinguishing categories (3), it is simplest here to discuss them in relation to their hosts.

What constitutes a bacteriocin is still arguable $(11,104)$, but in this review I use Nomura's (94) definition of bacteriocins as nonreplicating, bactericidal proteincontaining substances which are produced by certain strains of bacteria and are active against some other strains of the same or closely related species. This definition includes heterogeneous substances ranging from low-molecular-weight compounds to high-molecular-weight particles resembling bacteriophage protein components. It includes complete phage-like particles and small-headed "killer particles" containing both protein and nucleic acid $(2,126)$ as well as low molecular weight $\left(2 \times 10^{5}\right)$ substances sensitive to proteases and nucleases (112). Ackermann \& Brochu (2) summarize the grounds for considering the large phage-like particles simply as defective phages but refer to them as particulate bacteriocins. Bradley (11) classified bacteriocins into two broad types: a group of low molecular weight trypsin-sensitive, thermostable bacteriocins and a group of high molecular weight, trypsin-resistant, thermolabile bacteriocins. Although other groups clearly exist (e.g. 129) and a more satisfactory classification is desirable $(94,104)$, it is still premature to expand Bradley's classification (11).

Bacteriocin nomenclature is in an unfortunate state because some names are derived from the host genus, others from the host species, e.g. agrocins of Agrobacterium species, but syringacins of Pseudomonas syringae. Furthermore, names appropriate for bacteriocins have recently been used for completely unrelated compounds, e.g. corynecins for chloramphenicol analogs produced by a Corynebacterium species (120). Names derived from the species can be awkward, but nevertheless at least identify the producer. In many cases, it may be expedient simply to use trivial names to refer to bacteriocins produced by particular strains, such as bacteriocin 84 produced by $A$. radiobacter strain 84 (68). Classification and nomenclature will be improved when more bacteriocins are purified and characterized, and a genetic basis for their production established.

\section{NEW AND UNUSUAL PHAGES}

Since the reviews of Stolp (116) and Okabe \& Goto (98), a number of virulent and temperate phages of phytopathogenic bacteria have been studied (see supplementary bibliography) with respect to biological, chemical, and physical 
characteristics; disease forecasting; phage typing; and epidemiology. Primary phage hosts not mentioned in the previous reviews include $C$. insidiosum (27), C. michiganense $(37,132), C$. nebraskense (128), Erwinia uredovora (55), E. nigrifluens (138), P. caryophylli (93), P. tomato, P. marginalis, P. viridiflava, P. savastanoi, $P$. pastinaceae $(8), X$. carotae, $X$. vesicatoria $(72)$, and $X$. phaseoli var. sojensis (95). Phages have also been reported for $E$. herbicola (58), a nonpathogen associated with the fireblight organism, E. amylovora.

A number of phages of plant pathogens have been reported which are of interest because of unusual morphology or novel biochemical properties. The filamentous phage Xf for $X$. oryzae (74) has a protein coat unusually high in hydrophiobic amino acids (79) which may account for its lability to organic solvents and to low concentrations of sodium lauryl sulfate. In phage XP-12 of $X$. oryzae, 5-methylcytosine completely replaces cytosine (75); this replacement imparts unusual physical properties to the DNA (38). The double-stranded RNA, enveloped virus $\phi 6$ of $P$. phaseolicola $(113,127)$, is thus far in a class by itself (3) and is the most extensively characterized phage of phytopathogenic bacteria (26, $42,70,71,87 \mathrm{a}, 107-109,113,115,121 \mathrm{a}-124,127)$. A number of both temperate and virulent phages of $A$. tumefaciens have been studied (see supplementary bibliography), principally because of the possibility that they carry virulence determinants; this possibility is now considered highly unlikely $(32,110)$. Electron micrographs show typical bacteriophage particles associated with an unusual host, Spiroplasma citri, a helical organism without a true cell wall (25). The virus-like particles found associated with mycoplasma-like organisms of SM Stolbur agent (50), aster-yellows (5), and clover phyllody (52) may belong to a new virus class because they are morphologically unlike any other phages. Viruses of these agents are likely to be even more challenging to work with because of the difficulty of culturing their hosts.

\section{BACTERIOCINS}

Few bacteriocins of phytopathogenic bacteria have been discovered, much less characterized. Bacteriocins, or antagonisms between strains that might be due to bacteriocins, have been reported for the following: $A$. radiobacter $(68,126), A$. tumefaciens $(43,117,126), C$. michiganense (35), C. insidiosum (90), E. carotovora var. atroseptica, E. carotovora var. carotovora, E. chrysanthemi, Erwinia sp. from sugar beet (W.-L. Hsiang, M. N. Schroth and S. V. Thomson, personal communication), E. carotovora (syn. E. aroideae), E. chrysanthemi (syn. E. carotovora var. zeae), E. herbicola (syn. E. lathyri), E. salicis (56), E. uredovora (55), E. quercina (59), P. aptata, P. lachrymans (57), P. glycinea, P. phaseolicola (129), P. syringae $(82,129), P$. morsprunorum $(49,78,82)$, and $P$. solanacearum $(1,28,96)$. Specific antagonism between $P$. solanacearum strains was reported by Okabe (96), but it is not clear whether bacteriocins were involved since the inhibitory effects were considered bacteriostatic. Unpublished results are cited by Hamon et al (57) for bacteriocin production by $X$. albilineans, $X$. betiicola (sic), X. juglandis, $X$. phaseoli, and $X$. vesicatoria.

A number of bacteriocins of Agrobacterium species have been studied, but even 
here the full activity spectrum has not been determined $(43,68,125,126)$. Agrobacteriocin 1 (117) of $A$. tumefaciens and bacteriocin 84 of $A$. radiobacter (W. P. Roberts, personal communication) are both of low molecular weight, perhaps only oligopeptides. If so, these antibiotics may fall outside the current definition of bacteriocins. Bacteriocin 84 may act by interfering with DNA synthesis, since incorporation of thymidine, but not uridine, stopped soon after bacteriocin addition to a sensitive culture (W. P. Roberts, personal communication). Nothing is known of the mode of action of any other bacteriocins of phytopathogenic bacteria.

The majority of the bacteriocins for phytopathogenic bacteria are heatsensitive or trypsin-resistant or both, suggesting they may be high-molecular weight (11). Such bacteriocins are produced by strains of $C$. michiganense (35), $E$. carotovora, E. chrysanthemi, E. herbicola, E. salicis (56), P. aptata, P. lachrymans (57), P. glycinea, P. phaseolicola, P. syringae (129), and P. solanacearum (28). This group includes both inducible $(28,129)$ and noninducible bacteriocins $(35)$. Other bacteriocins produced by strains of $C$. insidiosum (90), $C$. michiganense (35), P. glycinea, P. phaseolicola, and $P$. syringae (129) apparently belong to the second major group of bacteriocins, those of low molecular weight (11). Additional groups, sensitive to both heat and proteolytic enzymes, resistant to both heat and enzymes, or showing differential sensitivity to trypsin and pronase have also been reported for P. glycinea, P. phaseolicola, or P. syringae (129).

Particulate contractile bacteriocins have been observed for $P$. syringae 4-A (53) and $P$. syringae W-1 (J. R. Imler and A. K. Vidaver, unpublished results), while killer particles have been described for strains 396 and 0362 of $A$. tumefaciens and strain 8149 of $A$. radiobacter (126). Other high molecular weight bacteriocins remain to be characterized.

Phytopathogenic bacteria thus produce a diverse array of bacteriocins. A wealth of material awaits further investigation.

\section{DESIRABLE ATTRIBUTES OF SELECTIVE CONTROL AGENTS}

There are risks in using broad-spectrum chemicals and antibiotics to control plant pathogens. Several commonly used fungicides are mutagenic in both prokaryotic and eukaryotic cells (see 13); all mutagens also have some carcinogenic activity. Streptomycin-resistant mutants of E. amylovora have arisen in nature as the result of streptomycin application (see 111). Antibiotic-resistant mutants of plant pathogens are undesirable enough, but agricultural use of antibiotics with medical applications might result in the selection or induction of antibiotic-resistant animal or human pathogens. There are already examples of fertility (F) factor and resistance $(R)$ factor transfers between potential human pathogens and plant pathogens. The $\mathrm{R}$ factors are the prototypical drug-resistance vectors and $\mathrm{F}^{\prime}$ factors can transfer a variety of genes between bacterial hosts. Thus $\mathrm{F}^{\prime}$ lac has been transferred from Escherichia coli to Erwinia spp. (18) and different R factors can be transferred from E. coli and Shigella flexneri to Erwinia spp. (19) and from $P$. aeruginosa to a number of plant pathogenic Pseudomonas spp. $(76,100)$. The destruction of beneficial species of bacteria must also be considered. 
Clearly there is a need for more selective, less persistent, and more environmentally acceptable agents for control of plant pathogens than very broad-spectrum chemicals and antibiotics. Useful bacteriophages and bacteriocins ought to have most of the attributes considered desirable for microbial control of insects (16), namely reasonable persistence, safety, aesthetic acceptability, ability to control to subeconomic concentrations, predictable control, ease of production, low cost, ease of storage, and èase of application. Bacteriophages and bacteriocins ought to have a reasonably broad killing spectrum; specificity against only one or a few strains of a species is useless for control. In our laboratory we generally limit extensive investigation to bacteriocins which kill a minimum of $40 \%$ of related test strains. Ideally, bacteriocins either should be inducible or be produced by derepressed mutants to obtain reasonable yields. A highly undesirable property is the capacity to act as a genetic vector; bacteriophages, which can spread rapidly, could have this property.

\section{BACTERIOPHAGES AS CONTROL AGENTS}

Numerous attempts have been made to control human and plant diseases with bacteriophages $(98,103,116)$. At present, medical uses are rare, but phages in tablet form are claimed to be effective in the therapy and prophylaxsis of bacillary dysentery (84). There has been more current interest in plant disease control. However, neither recent $(10,20,22,24,73,118)$ nor previous investigators (see 98,116$)$ used purified phage preparations. While it is likely that phages were, indeed, the active agents in the crude lysates, the observed effects might have been due to medium components or metabolic products. When bacteriophages were applied first, all investigators to date have found marked protection from disease symptoms. The phages were inoculated into stems (118), applied as a spray $(20,22,24)$ or in a dip $(10,73)$. In all cases the phage:bacterium ratios were $10: 1$ or higher. However, application of phage simultaneously with the pathogen or after inoculation of the plant with the pathogen reduced or eliminated the protective effect, for unknown reasons. Bacteriocins, as shown below, can also protect against bacterial infection when added first, but their effectiveness decreases when added simultaneously with, or after the bacteria.

Despite some potential for success as prophylactic control agents, bacteriophages are not recommended as control agents for the following reasons [other considerations have been previously mentioned (98)]. 1. Bacteriophages can mutate from virulent to temperate (69); lysogeny of susceptible cells would make them immune to further attack by the virulent parent phage or related phage. The host can also mutate to resistance. 2. Bacteriophages may transduce various characters from one host to another, possibly including virulence for the plant host. In this regard Okabe \& Goto's report (97) of transduction of virulence in $P$. solanacearum needs to be substantiated. The conjugational transfer of virulence to avirulent strains in Erwinia amylovora (101) suggests that phages might transduce this character. 3. Bacteriophages can carry genes for toxins resulting in lysogenic conversion of nonpathogens or change pathogen virulence (e.g. 40, 41, 
61). Probable lysogenic conversion accompanying loss of virulence has been reported for $X$. citri (136). These mechanisms, (2 or 3) may account in part for the emergence of new pathogens. 4. Bacteriophage action is strongly influenced by environmental conditions such as temperature, which may result in an altered host range (130) or curtail infection $(22,23)$. 5. Transducing phages can introduce active prokaryotic genes into plant and animal cells (for reviews see 9, 17, 87). While this scenario might seem unlikely because of dominance and the multigenic control of eukaryotic phenotypic characteristics, Zhdanov \& Tikchonenko's review (139) and Erskine's results (44) suggest that such a possibility for plant pathogens is not farfetched. Erskine (44) found a complete correlation between toxicity of a phage to rabbits and the virulence of the bacterial host, $E$. amylovora, in which the phage was propagated. The same phage propagated in virulent or weakly virulent strains of E. amylovora, or a saprophyte was respectively toxic, less toxic, or nontoxic. Killed whole cells or four types of artificially lysed cells of noninfected bacteria showed little or no toxicity. Confirmation and extension of this study will be of great interest.

\section{BACTERIOCINS AS CONTROL AGENTS}

\section{Control of Pathogens by Bacteriocin Producer Strains}

Dramatic decreases in disease (up to $99 \%$ control) have been obtained by inoculating seeds or roots with nonpathogenic bacteriocin-producing Agrobacterium radiobacter. This procedure controlled crown gall of peaches in Australia (62, 67, 92). Comparable results were obtained with inoculation of cherries in the northwestern USA (88). Preliminary results indicate that bacteriocin-producing, nonpathogenic $C$. michiganense can control tomato canker (36). Control in these cases was achieved by prior inoculation with the nonpathogen. If plants were inoculated with pathogens and the control agent was used simultaneously, most disease symptoms were prevented. Control decreased if the pathogen was inoculated first; for example, if strain 84 (a producer of bacteriocin 84 ) was added to wounds $2 \mathrm{hr}$ after inoculation with pathogenic $A$. tumefaciens 27, 'gall formation occurred in tomato seedlings. Galls increased in size as application of strain 84 was delayed. Detectable galls were absent if strain 84 was added first (62).

In control of crown gall by $A$. radiobacter strain 84 , there is a complete correlation between bacteriocin sensitivity of pathogenic strains of $A$. tumefaciens to bacteriocin 84 in vitro and the biological control in plants, except for an $A$. tumefaciens strain which produces a bacteriocin active against $A$. radiobacter strain 84 (68). Sensitivity to bacteriocin 84 is coded by a plasmid gene in the sensitive, pathogenic strains $(43,133)$. These sensitive strains harbor a large plasmid (137). However, not all pathogenic plasmid-containing A. tumefaciens strains are sensitive to bacteriocin $84(43)$.

Nevertheless, it is not certain that control is explained by bacteriocin production. Attempts to detect production of bacteriocin 84 in inoculated plants have so far been unsuccessful (A. Kerr, personal communication). Even if bacteriocin production occurs in the plant, it may not be in amounts that could account for 
control (but see below). For example, only small amounts of bacteriocin were produced by uninduced $P$. syringae strains in vitro and also in bean leaves inoculated with two different producers (A. K. Vidaver and M. Thomas, unpublished results). Since bacteriocin 84 has not been purified and characterized, it is not known whether the bacteriocin alone would be effective in control of $A$. tumefaciens. A single application of concentrated crude culture fluid sterilized with chloroform is partially effective in control but not as effective as an application of the living strain 84 (W. P. Roberts, personal communication).

The mechanism of control of $A$. tumefaciens strains may be more complex than by simple killing by bacteriocin; pathogenic bacteria that become resistant to bacteriocin 84 simultaneously may lose pathogenicity (68) and the large plasmid or a part of the plasmid that carries the genes for pathogenicity (110). This linkage between pathogenicity and sensitivity to bacteriocin might explain the effectiveness and duration of biological control.

The possibility that production of bacteriocin may not always be sufficient for control of crown gall is suggested by the discovery that $A$. radiobacter strain S1005, which produces bacteriocin S1005, does not control pathogenic A. tumefaciens B6 in the plant, although B6 is sensitive to bacteriocin S1005 in vitro (A. Kerr, personal communication). Unlike the case with strain 84 , S1005 bacteriocin-resistant colonies are as virulent as the parent strain and also retain the large plasmid (43). Unlike the producer strain 84 (J. Schell, personal communication) the producer strain S1005 does not harbor any detectable plasmid (137).

Obvious questions are whether strain S1005 or other bacteriocin-producing strains that are ineffective in biological control produce bacteriocins in the plant and if so, are these bacteriocins inhibited by plant materials? In vitro studies show that the medium is critical for bacteriocin activity or production (A. Kerr, personal communication). Another possible explanation for ineffective biological control strains is that a close genetic linkage between sensitivity and virulence may not exist for these bacteriocin sensitive strains (125), A. Kerr (personal communication). For other strains, the pathogen may escape control by mutating to resistance.

The suppression of pathogenic Erwinia amylovora by nonpathogenic E. herbicola $(45,51,85,105,135)$ and of pathogenic Pseudomonas syringae by an otherwise indistinguishable saprophyte (31), and interference between plant mycoplasma-like organisms (e.g. 48,81$)$ suggest analogies with the crown-gall phenomenon. Further studies should prove of great interest.

\section{Control of Pathogens by Bacteriocin Preparations}

Presently only syringacins 4-A (53) and W-1 (J. R. Imler and A. K. Vidaver, unpublished results) have been purified and tested in preliminary fashion against $P$. phaseolicola and P. glycinea. Both are inducible, particulate bacteriocins.

When purified syringacin 4-A was sprayed on bean leaves prior to spray inoculation with $P$. phaseolicola strain BE under pressure (water-soaking), as little as $3 \mathrm{ng}$ per leaf reduced the lesion count from 250 (average) to zero. The lesion count was at least 50 if bacteriocin was applied 5 min after pathogen inoculation 
(A. K. Vidaver and M. Thomas, unpublished results). Similar prophylactic effectiveness has been reported with crude bacteriocin preparations from C. michiganense (36).

Seed treatment is a promising use for bacteriocins because of pathogen dissemination via seed (see 6). Bacteriocin 4-A can protect soybean seed against challenge with $P$. glycinea $\left(10^{7} \mathrm{CFU} / \mathrm{ml}\right)$; without bacteriocin protection, germination was reduced about $20 \%$. Cost of materials for such treatment with syringacin 4-A, based on 200,000 seeds per acre is about 0.49 US dollars per hectare ( $\$ 0.20$ per acre). This figure would be reduced about tenfold if the mitomycin $C$ induction step of bacteriocin preparation could be eliminated. We also observed an unexplained increase in germination of poor quality seed (from 68 to $77 \%, P=0.01)$ after a ten-minute dip into purified syringacin 4 -A. Germination also increased in seed drenched with fungicide $\left(\operatorname{Captan}^{\circledR}\right)$; the bacteriocin effects were then masked (A. K. Vidaver and R. Carlson, unpublished results).

Little research has been done on the use of bacteriocins in mammalian systems. However, bacteriocin treatment for antibiotic-resistant $P$. aeruginosa [an occasional plant pathogen, $(30)]$ has been effective in mice $(54,86,114)$.

\section{CAVEATS}

Since I advocate more research on bacteriocins, it is perhaps appropriate to offer some cautionary advice.

\section{Artifacts}

Detection of bacteriocins is still an art and an imperfect one. Specific inhibition is not always due to a bacteriocin; for example, the specific inhibition of Neisseria gonorrhoeae by strains of the same species was due to production of inhibitory free fatty acids and lysophosphatidylethanolamine (134). Ammonia production by some strains of $P$. pseudomallei (106) and peroxide production by strains of group A streptococci (80) also caused specific inhibition which at first was interpreted as bacteriocin production.

\section{Bacteriocin Inhibitors}

A number of substances have been reported to inhibit bacteriocin production or destroy active bacteriocin $(14,46,63,90,129,131)$. The inhibitors may be active against bacteriocin produced by the same strain, as in $C$. insidiosum (90), or a different strain, as in $P$. syringae (129). Such inhibitors may be suppressed by altering the medium $(14,131)$ or destroyed, for example, by heat treatment which can differentially inactivate the inhibitor but not the bacteriocin (90). Purification of the bacteriocin can also remove inhibitors (15).

\section{Avoid Use of Crude Bacteriocin Preparations}

Conventional purification procedures generally will assure that the observed effects arise from bacteriocins and not from contaminants. Purification can also 
remove inhibitors and prevent introduction (into seeds or plants) of products potentially toxic to beneficial microorganisms or plants. In addition, purified bacteriocins will not provide an unwanted growth medium for the target or other microorganism. Purification should also allow detection of nucleic acid, if any. The objections to use of phage also apply to bacteriocins or killer particles containing nucleic acid.

\section{PERSPECTIVES AND RECOMMENDATIONS}

Much more needs to be learned about bacteriophages and bacteriocins of phytopathogenic bacteria. These agents are not only of intrinsic interest, but also potentially useful for genetic studies of pathogenicity. While phages are not recommended for use as control agents, both phages and bacteriocins are of value in disease forecasting, identification of strains (typing), and taxonomic studies (see supplementary bibliography).

Research should be expanded on bacteriocins because they possess most of the desirable attributes of control agents, particularly specificity of action against the target organism.

The greatest potential use of bacteriocins at present scems to be prophylactic treatment for seed- or tuber-borne diseases, prevention of secondary spread from infected plants, and protection of high value crops, for example, apple and pear blossoms against $E$. amylovora. In the latter case, a thorough understanding of epidemiology (see 111) should enable careful and timely application. The bacteriocins which have been tested so far show little promise for therapeutic use or prevention of secondary spread of systemic diseases or use against organisms which survive well in soil, for example, $P$. solanacearum.

If bacteriocin producers are used for biological control of pathogens and such control is attributed to bacteriocin production, it should be shown that bacteriocins are the active agent. Both the producer and target organisms should be tested for genetic transfer: in vitro between producer and target organisms; and in plants, from producer to the plant and from target bacterium to producer. This recommendation is made to avoid the introduction of deleterious genes into either the bacteriocin producer strain or plants. Nonvirulent forms of pathogens should be tested for reversion rates to virulence.

The emergence of bacteriocin-resistant mutants should not mitigate against use of bacteriocins. Such mutants should be tested for pathogenicity and altered bacteriocin sensitivity because resistance to bacteriocin may be linked to the loss of pathogenicity (68), or the resistant mutants may gain susceptibility to different bacteriocins, or both. For example, 57 out of 59 syringacin 4-A-resistant mutants arising from three different susceptible species of fluorescent pseudomonads developed sensitivity to the complementary bacteriocin W-1 (A. K. Vidaver and S. Buckner, unpublished results). The potential usefulness of a bacteriocin is retained or increased if either or both of these mechanisms operate. In addition, it 
would be interesting to know whether bacteriocin production or sensitivity was due to a plasmid or a chromosomal determinant.

Of prime importance is the recommendation that at least two and preferably three serologically unrelated bacteriocins be used simultaneously. No matter how effective a single bacteriocin may be, it should not be used alone because the target organism is likely to develop resistance to it. The use of even two bacteriocins with overlapping activity spectra would decrease the probability of mutation to resistance to a frequency of $10^{-18}$ per generation, assuming spontaneous mutation frequencies of $10^{-8}$ per cell generation.

The use of protectants against ultraviolet light or other inactivating agents and microencapsulation $(91,121)$ should increase the effective lifetime of bacteriocins. Such treatment would help overcome the major disadvantage of bacteriocins, their susceptibility to destruction by many physical and chemical agents in the environment. By analogy with a number of antibiotics, the protein nature of bacteriocins also places some restriction on their manufacture, storage, and application.

Prospective bacteriocins must not only be effective; they must be economically competitive with less selective bactericides. Bacteriocins are likely to be economical to produce and use because current production techniques for traditional antibiotics can be employed, including genetic manipulation for product improvement. In the one instance mentioned above, the estimated material cost was about 0.49 US dollars per hectare ( $\$ 0.20$ per acre).

Finally, the role of patents must be considered as it affects the development and use of bacteriocins. In this connection, a current review is instructive (64).

\section{ACKNOWLEDGMENTS}

I thank my colleagues who provided me with information and unpublished manuscripts. I also thank S. Buckner for bibliographic assistance. Work from this laboratory has been supported by grants from the United States Department of Agriculture and the National Institutes of Health.

\section{Literature Cited}

1. Abo-El-Dahab, M. K., El-Goorani, M. A. 1969. Antagonism among strains of Pseudomonas solanacearum. Phytopathology 59:1005-7

2. Ackermann, H.-W., Brochu, G. 1973. Particulate bacteriocins. In Handbook of Microbiology, Vol. I, Organismic Microbiology, ed. A. I. Laskin, H. A. Lechevalier, 629-32. Cleveland: CRC. 924 pp.

3. Ackermann, H.-W., Eisenstark, A. 1974. The present state of phage taxonomy. Intervirology 3:201-19

4. Adams, M. 1959. Bacteriophages. New York: Interscience. 592 pp.
5. Allen, T. C. 1972. Bacilliform particles within asters infected with a western strain of aster yellows. Virology 47: 491-93

6. Baker, K. F. 1972. Seed pathology. In Seed Biology, ed. T. T. Kozlowski, II:318-416. New York: Academic. $447 \mathrm{pp}$.

7. Billing, E. 1969. Isolation, growth and preservation of bacteriophages. In Methods in Microbiology, ed. J. N. Norris, D. W. Ribbons, 3B:315-29. New York: Academic. 369 pp.

8. Billing, E. 1970. Further studies on the phage sensitivity and the determina- 
tion of phytopathogenic Pseudomonas spp. J. Appl. Bacteriol. 33:478-91

9. Bottino, P. J. 1975. The potential of genetic manipulation in plant cell cultures for plant breeding. Radiat. Bot. 15:1-16

10. Boyd, R. J., Hildebrandt, A. C., Allen, O. N. 1971. Retardation of crown gall enlargement after bacteriophage treatment. Plant Dis. Reptr. 55:145-48

11. Bradley, D. E. 1967. Ultrastructure of bacteriophages and bacteriocins. Bacteriol. Rev. 31:230-314

12. Brandis, H., Smarda, J. 1971. Bacteriocine und Bacteriocinaehnliche Substanzen (Infektionskrankheiten und ihre Erreger, Bd. 11). Jena, E. Germany: Fischer. 407 pp.

13. Bridges, B. A. 1975. The mutagenicity of captans and related fungicides. $\mathrm{Mu}$ tat. Res. 32:3-34

14. Brubaker, R. R., Surgalla, M. J. 1961. Pesticins. I. Pesticin bacterium interrelationships, and environmental factors influencing activity. J. Bacteriol. 82:940-49

15. Brubaker, R. R., Surgalla, M. J. 1962. Pesticins. II. Production of pesticin I and II. J. Bacteriol. 84:539-45

16. Burges, H. D., Hussey, N. W. 1971. Microbial Control of Insects and Mites. New York: Academic. $861 \mathrm{pp}$.

17. Chaleff, R. S., Carlson, P. S. 1974. Somatic cell genetics of higher plants. Ann. Rev. Genet. 8:267-78

18. Chatterjee, A. K., Starr, M. P. 1972. Genetic transfer of episomic elements among Erwinia species and other enterobacteria: $\mathrm{F}^{\prime} \mathrm{lac}^{+}$. J. Bacteriol. 111:169-76

19. Chatterjee, A. K., Starr, M. P. 1972. Transfer among Erwinia spp. and other enterobacteria of antibiotic resistance carried on $\mathrm{R}$ factors. $\mathrm{J}$. Bacteriol. 112:576-84

20. Civerolo, E. L. 1970. Comparative relationships between two Xanthomonas pruni bacteriophages and their bacterial host. Phytopathology 60:1385-88

21. Civerolo, E. L. 1972. Interaction between bacteria and bacteriophages on plant surfaces and in plant tissues. Proc. Third Int. Conf. Plant Pathog. Bact.. Wageningen, April 14-21, 1971, 25-37. Wageningen: PUDOC

22. Civerolo, E. L. 1973. Relationships of Xanthomonas pruni bacteriophages to bacterial spot disease in Prunus. Phytopathology 63:1279-84

23. Civerolo, E. L. 1974. Temperature effects on the relationships between Xanthomonas pruni and its virulent phages. Phytopathology 64:1248-55

24. Civerolo, E. L., Keil, H. L. 1969. Inhibition of bacterial spot of peach foliage by Xanthomonas pruni bacteriophage. Phytopathology 59:1966-67

25. Cole, R. M., Tully, J. G., Popkin, T. J., Bove, J. M. 1973. Morphology, ultrastructure, and bacteriophage infection of the helical mycoplasma-like organism (Spiroplasma citri gen. nov., sp. nov.) cultured from "stubborn" disease of citrus. J. Bacteriol. 115: 367-86

26. Coplin, D. L., Van Etten, J. L., Koski, R. K., Vidaver, A. K. 1975. Intermediates in the biosynthesis of doublestranded ribonucleic acids of bacteriophage $\phi 6$. Proc. Natl. Acad. Sci. USA 72:849-53

27. Cook, F. D., Katznelson, H. 1960. Isolation of bacteriophages for the detection of Corynebacterium insidiosum, agent of bacterial wilt of alfalfa. Can. J. Microbiol. 6:121-25

28. Cuppels, D., Hanson, R., Kelman, A. 1975. Production of bacteriocin-like compounds by Pseudomonas solanacearum. Abstr. Ann. Meet. Am. Phytopathol. Soc., Aug. 10-14. No. 155

29. Daltop, A. J., Haguenau, F. Ultrastructure of A nimal Viruses and Bacteriophages: An Atlas. 1973. New York: Academic. $413 \mathrm{pp}$.

30. Doudoroff, M., Palleroni, N. J. 1974. Genus Pseudomonas. In Bergey's Manual of Determinative Bacteriology, ed. R. E. Buchanan, N. E. Gibbons, 217-243. Baltimore: Williams \& Wilkins. 1268 pp. 8th ed.

31. Dowler, W. M. 1972. Inhibition of Pseudomonas syringae by saprophytic bacterial isolates in culture and in infected plant tissues. See Ref. 21, pp. 307-11

32. Drlica, K. A., Kado, C. I. 1975. Crown gall tumors: are bacterial nucleic acids involved? Bacteriol. Rev. 39:186-96

33. Dye, D. W. et al 1975. Proposals for a reappraisal of the status of the names of plant pathogenic Pseudomonas species. Int. J. Syst. Bacteriol. 25:252-57

34. Dye, D. W., Lelliott, R. A. 1974. Genus Xanthomonas. See Ref. 30, pp. 243-49

35. Echandi, E. 1976. Bacteriocin production by Corynebacterium michiganese. Phytopathology 66:430-32

36. Echandi, E. 1975. Biological control 
of bacterial canker of tomato with bacteriocins from Corynebacterium michiganense. See Ref. 28, No. 154

37. Echandi, E., Sun, M. 1973. Isolation and characterization of a bacteriophage for the identification of Corynebacterium michiganese. Phytopathology 63:1398-1401

38. Ehrlich, M., Ehrlich, K., Mayo, J. A. 1975. Unusual propert ies of the DNA from Xanthomonas phage XP-12 in which 5-methyl-cytosine completely replaces cytosine. Biochem. Biophys. Acta 395:109-19

39. Eisenstark, A. 1967. Bacteriophage techniques. In Methods in Virology, ed. K. Maramorosch, H. Koprowski, 1:450-524. New York: Academic. $640 \mathrm{pp}$.

40. Eklund, M. W., Poysky, F. T. 1974. Interconversion of type $C$ and $D$ strains of Clostridium botulinum by specific bacteriophages. Appl. Microbiol. 27:251-58

41. Eklund, M. W., Poysky, F. T., Meyers, J. A., Pelroy, G. A. 1974. Interspecies conversion of Clostridium botulinum type $\mathrm{C}$ to Clostridium novyi type A by bacteriophage. Science 186:456-58

42. Ellis, L F., Schlegel, R. A. 1974. Electr on microscopy of Pseudomonas $\phi 6$ bacteriophage. J. Virol. 14:1547-51

43. Engler, G. et al 1975. Agrocin-84 sensitivity: A plasmid determined propert y in Agrobacterium tumefaciens. Mol. Gen. Genet. 138:345-50

44. Erskine, J. M. 1973. Association of virulence characteristics of Erwinia amylovora with toxigenicity of its phage lysates to rabbit. Can. J. Microbiol. 19:875-77

45. Erskine, J. M., Lopatecki, L. E. 1975. In vitro and in vivo interactions between Erwinia amylovera and related saprophytic bacteria. Can. J. Microbiol. 21:35-41

46. Foulds, J. D., Shemin, D. 1969. Concomitant synthesis of bacteriocin and bacteriocin inactivator from Serratia marcescens. J. Bacteriol. 99:661-66

47. Fraenkel-Conrat, H. 1974. Descriptive catalogue of viruses. Comprehensive Virology. ed. H. Fraenkel-Conrat, R. R. Wagner, Vol. 1. New York: Plenum. 191 pp.

48. Freitag, J. H. 1964. Interaction and mutual suppression among three strains of aster yellows virus. Virology 24:401-13

49. Garrett, C. M. E., Panagopoulos,
C. G., Crosse, J. E. 1966. Comparison of plant pathogenic pseudomonads from fruit trees. J. Appl. Bacteriol. 29:342-56

50. Giannotti, J., Devauchelle, G., Vago, C. Marchoux, G. 1973. Rod-shaped virus-like particles associated with degenerating mycoplasma in plant and insect vector. Ann. Phytopathol. 5:461-66

51. Goodman, R. N. 1965. In vitro and in vivo interactions between components of mixed bacterial cultures isolated from apple buds. Phytopathology 55:217-21

52. Gourett, J. P., Maillet, P. L., Gouranton, J. 1973. Virus-like particles associated with mycoplasmas of clover phyllody in the plant and in the insect vector. J. Gen. Microbiol. 74:241-49

53. Haag, W. L., Vidaver, A. K. 1974. Purification and characterization of syringacin 4-A, a bacteriocin from Pseudomonas syringae 4-A. Antimicrob. Agents Chemother. 6:76-83

54. Haas, H., Sacks, T., Saltz, N. 1974. Protective effect of pyocin against lethal Pseudomonas aeruginosa infections in mice. J. Infect. Dis. 129: 470-72

55. Hamon, Y., Peron, Y. 1962. Les bacteriocines, elements taxonomiques eventuels pour certains bacteries. $C$. R. Acad. Sci. 254:2868-70

56. Hamon, Y., Peron, Y, 1961. Les proprietes antagonistes reciproques parmi les Erwinia. Discussion de la position taxonomique de ce genre. $C$. R. Acad. Sci. 253:913-15

57. Hamon, Y., Veron, M., Peron Y. 1961. Contribution a l'etude des proprietes lysogenes et bacteriocinogenes dans le genre Pseudomonas. Ann. Inst. Pasteur Paris 101:738-53

58. Harrison, A., Gibbons, L. N. 1975. The isolation and cliaracterization of a temperate phage Y46/(E2), from Erwinia herbicola Y46. Can. J. Microbiol. 21:937-44

59. Hildebrand, D. C., Schroth, M. N. 1967. A new species of Erwinia causing the drippy nut disease of live oaks. Phytopathology 57:250-53

60. Holloway, B. W., Krishnapillai, V. 1975. Bacteriophages and bacteriocins. In Genetics and Biochemistry of Pseudomonas. ed. P. H. Clarke, M. H. Richmond, 99-132. New York: Wiley. $366 \mathrm{pp}$.

61. Holmes, R. K., Barksdale, L. 1969. Genetic analysis of tox ${ }^{+}$and tox 
bacteriophages of Corynebacterium diphtheriae. J. Virol. 3:586-98

62. Htay, K., Kerr, A. 1974. Biological control of crown gall: seed and root inoculation. J. Appl. Bacteriol. 37: 525-30

63. Ikeda, M. 1970. Pyocin inactivation by cell free supernatant of Pseudomonas aeruginosa culture. Its quantitative assay and approaches to the established method. Nagasaki Igakkai Zasshi 45:621-31

64. Irons, E. S., Sears, M. H. 1975. Patents in relation to microbiology. Ann. Rev. Microbiol. 29:319-32

65. Kay, D. 1972. Methods for studying the infectious properties and multiplication of bacteriophage. See Ref. 7, 7A:191-262

66. Kay, D. 1972. Methods for the determination of the chemical and physical structure of bacteriophages. See Ref. 7, 7A:263-313

67. Kerr, A. 1972. Biological control of crown gall: seed inoculation. J. Appl. Bacteriol. 35:493-97

68. Kerr, A.,

control of crown gall through bacteriocin production. Physiol. Plant $\mathrm{Pa}$ thol. 4:37-44

69. Kleczkowska, J. 1969. The mutation of some virulent rhizobiophages into the temperate form. Can. J. Microbiol. 15:1055-59

70. Kleinschmidt, W. J., Boeck, L. D., Van Frank, R. M., Murphy, E. B. 1973. Interferon production by $\phi 6$ Pseudomonas phaseolicola phage and its double-stranded RNA. Proc. Soc. Exp. Biol. Med. 144:304-7

71. Kleinschmidt, W. J., Van Etten, J. L., Vidaver, A. K. 1974. Influence of molecular weights of bacteriophage $\phi 6$ double-stranded ribonucleic acids on interferon induction. Infect. Immun. 10:284-85

72. Klement, Z. 1959. Some new specific bacteriophages for plant pathogenic Xanthomonas spp. Nature 184:1248-49

73. Kuo, T.-T., Chang, L.-C. Yang, C.M., Yang, S.-E. 1971. Bacterial leaf blight of rice plant. IV. Effect of bacteriophage on the infectivity of Xanthomonas oryzae. Bot. Bull. Acad. Sinica 12:1-9

74. Kuo, T.-T., Huang, T.-C., Chow, T.Y. 1969. A filamentous bacteriophage from Xanthomonas oryzae. Virology 39:548-55

75. Kuo, T.-T., Huang, T.-C., Teng, M. H. 1968. 5-Methylcytosine replacing cytosine in deoxyribonucleic acid of a phage of X. oryzae. J. Mol. Biol. 34: 373-75

76. Lacy, G. H., Leary, J. V. 1975. Transfer of antibiotic resistance plasmid RPI into Pseudomonas glycinea and Pseudomonas phaseolicola in vitro and in planta. J. Gen. Microbiol. 88: 49-57

77. Laskin, A. I., Lechevalier, H. A. 1973. See Ref. 2, pp. 573-650

78. Lazar, I., Crosse, J. E. 1969. Lysogeny, bacteriocinogeny, and phage types in plum isolates of Pseudomonas morsprunorum Wormald. Rev. Roum. Biol. Ser. Bot. 14:325-33

79. Lin, J.-Y., Wu, C.-C., Kue, T.-T. 1971. Amino acid analysis of the coat protein of the filamentous bacterial virus Xf from Xanthomonas oryzae. Virology 45:38-41

80. Malke, H., Starke, R., Jacob, H. E., Kohler, W. 1974. Bacteriocine-like activity of group-A streptococci due to the production of peroxide. J. Med. Microbiol. 7:367-74

81. Marchoux, G., Giannotti, J. 1971. Interferences entre deux mycoplasmoses vegetales. Physiol. Veg. 9: 595-610

82. Matthews, P. 1965. Bacteriocin activi$t y$ in Pseudomonas morsprunorum and P. syringae. John Innes Inst. Ann. Rept. 1964:35-36

83. Mayr-Harting, A., Hedges, A. J., Berkeley, R. C. W. 1972. Methods for studying bacteriocins. See Ref. 7, 7A: 315-422

84. Mazacek, M., Petera, A., 1969. Die Bakteriophagie in der Therapie und Prophylaxe der Infektionskrankheiten. Zentralbl. Bakteriol. Parasitenkd. Infektionskr. Hyg. Abt. I 211:385-94

85. McIntyre, J. L., K uć, J., Williams, E. B. 1973. Protection of pear against fire blight by bacteria and bacterial sonicates. Phytopathology 63:872-77

86. Merrikin, D. J., Terry, C. S. 1972. Use of pyocin 78-C2 in the treatment of Pseudomonas aeruginosa infection in mice. Appl. Microbiol. 23:164-65

87. Merril, C. R., Stanbro, H. 1974. Intercellular gene transfer $Z$. Pflanzenphysiol. 72:371-88

87a.Mindich, L., Cohen, J., Weisburd, M. 1976. Isolation of nonsense suppressor mutants in Pseudomonas. J. Bacteriol. 126:177-82

88. Moore, L. W. 1975. Biological control of crown gall with an antagonistic 
Agrobacterium species. See Ref. 28, No. 157

89. Murata, N., Starr, M. P. 1973. A concept of the genus Xanthomonas and its species in the light of segmental homology of deoxyribonucleic acids. Phytopathol. Z. 77:285-323

90. Nelson, G. A., Semeniuk, G. 1964. An antagonistic variant of Corynebacterium insidiosum and some properties of the inhibitor. Phytopathology 54:33035

91. Neogi, A. N., Allan, G. G. 1974. Controlled release pesticides: concepts and realization. Adv. Exp. Med. Biol. 47: 195-224

92. New, P. B., Kerr, A. 1972. Biological control of crown gall: field measurements and glasshouse experiments. $J$. Appl. Bacteriol. 35:279-87

93. Nishimura, J., Wakimoto, S. 1971. Ecological studies on bacterial wilt disease of carnation (Dianthus caryophyllus). 1. Some characteristics and mode of multiplication of Pseudomonas caryophylli phage. Ann. Phytopathol. Soc. Jpn. 37:301-6

94. Nomura, M. 1967. Colicins and related bacteriocins. Ann. Rev. Microbiol. 21:257-84

95. Numic, R. 1970. Bakteriofagi fitopatogenih bakterija Soje. Sarajevo Univ. Poljopriuredno-sum Fak. Rad. 19:187-224

96. Okabe, N. 1954. Studies on Pseud. solanacearum. V. Antagonism among the strains of $P$. solanacearum. Rept. Fac. Agric. Shizuoka Univ. 4:37-40

97. Okabe, N., Goto, M. 1955. Studies on Pseudomonas solanacearum. X. Genetic change of the bacterial strains induced by the temperate phage T-c200. Rept. Fac. Agric. Shizuoka Univ. 5:57-62

98. Okabe, N., Goto, M. 1963. Bacteriophages of plant pathogens. Ann. Rev. Phytopathol. 1:397-418

99. Ozeki, H. 1968. Methods for the study of colicins and colicinogeny. See Ref. 39, 4:565-92

100. Panopoulos, N. J., Guimaraes, W. V., Cho, J. J., Schroth, M. N. 1975. Conjugative transfer of Pseudomonas aeruginosa $\mathrm{R}$ factors to plant pathogenic Pseudomonas spp. Phytopathology $65: 380-88$

101. Pugashetti, B. K., Starr, M. P. 1975. Conjugational transfer of genes determining plant virulence in Erwinia amylovora. J. Bacteriol. 122:485-91

102. Raettig, H.-J. 1958. Bakteriophagie. Stuttgart: Fischer. 2 vols. 215 pp.,

\section{4 pp.}

103. Rautenshtein, Y. I. 1967. The role of bacteriophage for agricultural microbiology Skh. Biol. 2:499-507

104. Reeves, P. 1972. The Bacteriocins. New York: Springer. $142 \mathrm{pp}$

105. Riggle, J. H., Klos, E. J. 1972. Relationship of Erwinia herbicola to Erwinia amylovora. Can. J. Bot. 50:1077-83

106. Rogul, M., Carr, S. R. 1972. Variable ammonia production among smooth and rough strains of Pseudomonas pseudomallei: Resemblance to bacteriocin production. J. Bacteriol. 112: $372-80$

107. Sands, J. A. 1973. The phospholipid composition of bacteriophage $\phi 6$. Biochem. Biophys. Res. Commun. 55: $111-16$

108. Sands, J. A., Cupp, J., Keith, A., Snipes, W. 1974. Temperature sensitivity of the assembly process of the enveloped bacteriophage $\phi 6$. Biochem. Biophys. Acta 373:277-85

108a.Sands, J. A., Lowlicht, R. A. 1976. Temporal origin of viral phospholipids of the enveloped bacteriophage $\phi 6$. Can. J. Microbiol. 22:154-58

109. Sands, J. A., Lowlicht, R. A., Cadden, S. C., Haneman, J. 1975. Assembly of the enveloped bacteriophage $\phi 6$ in environments which perturb the host cell membranes. Can. J. Microbiol. 21: 1287-90

110. Schell, J. 1975. The role of plasmids in crown-gall formation by $A$. tumefaciens. In Genetic Manipulations with Plant Materials, ed. L. Ledoux, 163 -81. New York: Plenum. $601 \mathrm{pp}$.

111. Schroth, M. N., Thomson, S. V., Hildebrand, D. C., Moller, W. J. 1974. Epidemiology and control of fire blight. Ann. Rev. Phytopathol. 12: 389-412

112. Schwinghamer, E. A. 1975. Properties of some bacteriocins produced by Rhizobium trifolii. J. Gen. Microbiol. 91:403-13

113. Semancik, J. S., Vidaver, A. K., Van Etten, J. L. 1973. Characterization of a segmented double-helical RNA from

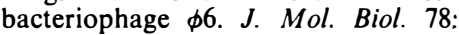
617-26.

114. Sezen, I. Y., Blobel, H., Scharmann, W. 1974. Possible use of pyocins against Pseudomonas aeruginosa. Zentralbl. Bakeriol. Parasitenkd. Infektionskr. Hyg. Abt. l Orig. Reihe A 229:205-8

115. Sinclair, J. F., Tzagoloff, A., Levine, D., Mindich, L. 1975. Proteins of 
bacteriophage $\phi 6 . J$. Virol. 16:685-95

116. Stolp, H. 1956. Bacteriophagenforschung und Phytopathologie (ein Sammelreferat). Phytopathol. Z. 26: 171-218

117. Stonier, T. 1960. Agrobacterium tumefaciens Conn. II. Production of an antibiotic substance. J. Bacteriol. 79: 889-98

118. Stonier, T., McSharry, J., Speitel, T. 1967. Agrobacterium tumefaciens Conn. IV. Bacteriophage $\mathrm{PB} 2_{1}$ and its inhibitory effect on tumor induction. J. Virol. 1:268-73

119. Tikhonenko, A. S. 1970. Ultrastructure of Bacterial Viruses. New York: Plenum. 294 pp.

120. Tomita, F., Nakano, H., Honda, H., Suzuki, T. 1974. Production of corynecins by chloramphenicol resistant mutants of Corynebacterium hydrocarboclastus. Agric. Biol. Chem. 38: 2183-90

121. Vandegaer, J. E. 1974. Microencapsulation: Processes and Applications. New York: Plenum. $180 \mathrm{pp}$.

121a.Van Etten, J., Lane, L., Gonzalez, C., Partridge, J., Vidaver, A. 1976. Comparative properties of bacteriophage $\phi 6$ and $\phi 6$ nucleocapsid. J. Virol. 18:652-58

122. Van Etten, J. L., Vidaver, A. K., Koski, R. K., Burnett, J. P. 1974. Base composition and hybridization studies of the three double-stranded RNA segments of bacteriophage $\phi 6 . J$. Virol. 13:1254-62

123. Van Etten, J. L., Vidaver, A. K., Koski, R. K., Semancik, J. S. 1973 RNA polymerase activity associated with bacteriophage $\phi 6$. J. Virol. 12: 464-71

124. Van Frank, R. M., Kleinschmidt, W. J. 1973. Concentration and purification of two small RNA viruses: mycophage PS-1 and bacteriophage $\phi 6 . A n$. Biochem. 55:601-8

125. Van Larebeke, N. et al 1975. Acquisition of tumour-inducing ability by non-oncogenic agrobacteria as a result of plasmid transfer. Nature 255: 742-43

126. Vervliet, G., Holsters, M., Teuchy, H., Van Montagu, M., Schell, J. 1975. Characterization of different plaqueforming and defective temperate phages in Agrobacterium strains. $J$. Gen. Virol. 26:33-48

127. Vidaver, A. K., Koski, R. K., Van Etten, J. L. 1973. Bacteriophage $\phi 6$ : a lipid-containing virus of Pseudomonas phaseolicola. J. Virol. 11:799-805
128. Vidaver, A. K., Mandel, M. 1974. Corynebacterium nebraskense, a new orange-pigmented phytopathogenic species. Int. J. Syst. Bacteriol. 24: 482-85

129. Vidaver, A. K., Mathys, M. L. Thomas, M. E., Schuster, M. L. 1972. Bacteriocins of the phytopathogens Pseudomonas syringae, $P$. glycinea, and $P$. phaseolicola. Can. J. Microbiol. 18:705-13

130. Vidaver, A. K., Schuster, M. L. 1969. Characterization of Xanthomonas phaseoli bacteriophages. J. Virol. 4:300-8

131. Wahba, A. H. 1963. The production and inactivation of pyocines. $J . H y g$. 61:431-41

132. Wakimoto, S., Vematsu, T., Mizukami, T. 1969. Bacterial canker disease of tomato in Ja pan. 2. Properties of bacteriophages specific for Corynebacterium michiganense (Smith) Jensen. Ann. Phytopathol. Soc. Jpn. 35:168-73

133. Watson, B., Currier, T. C., Gordon, M. P., Chilton, M-D., Nester, E. W. 1975. Plasmid required for virulence of Agrobacterium tumefaciens. J. Bacteriol. 123:255-64

134. Walstad, D. L., Reitz, R. C., Sparling, P. F. 1974. Growth inhibition among strains of Neisseria gonorrhoeae due to production of inhibitory free fatty acids and lysophosphatidylethanolamine: absence of bacteriocins. Infect. Immun. 10:481-88

135. Wrather, J. A., Kuc, J., Williams, E. B. 1973. Protection of apple and pear f ruit tissue against fireblight with nonpathogenic bacteria. Phytopathology 63:1075-76

136. Wu, W. C. 1972. Phage-induced alterations of cell disposition, phage adsorption and sensitivity, and virulence in Xanthomonas citri. Ann. Phytopathol. Soc. Jpn. 38:333-41

137. Zaenen, I., Van Larebeke, N., Teuchy, H., Van Montagu, M., Schell, J. 1974. Supercoiled circular DNA in crowngall inducing Agrobacterium strains. $J$. Mol. Biol. 86:109-27

138. Zeit oun, F. M., Wilson, E. E. 1969. The relation of bacteriophage to the walnut-tree pathogens, Erwinia nigrifluens and Erwinia rubrifaciens. Phytopathology 59:756-61

139. Zhdanov, V. M., Tikhonenko, T. I. 1974. Viruses as a factor of evolution: exchange of genetic information in the biosphere. Adv. Virus Res. 19: 361-94 